\title{
SKUBIOSIOS MEDICINOS PAGALBOS TEIKIMO RIZIKA SLAUGYTOJU巳 SVEIKATAI
}

\author{
Rasa Juozapavičienė, Vilma Daujotaitė \\ Kauno kolegijos Medicinos fakultetas
}

Raktažodžiai: rizika, sveikatos problemos, slaugytoja, skubioji medicinos pagalba.

\section{Santrauka}

Sveikatos priežiūros darbuotojai skubiają medicinos pagalbą dažniausiai teikia aplinkoje, kurios sąlygos laikomos vienomis iš nesaugiausių profesinių sąlygų. Darbinejje aplinkoje profesinè rizika sveikatai apima biologinius, cheminius, fizinius, ergonominius, psichosocialinius veiksnius, gaisro ir sprogimo bei elektros pavojus, kurie kelia grèsmę sveikatos priežiūros darbuotojų gyvybei, saugai ir gerovei. Tyrimo tikslas - atskleisti skubiosios medicinos pagalbos teikimo riziką slaugytojų sveikatai.

Tiriamieji. Tyrime dalyvavo 15 slaugytojų, dirbančių $\mathrm{X}$ greitosios medicinos pagalbos stotyje. Respondentai atrinkti, atsižvelgiant ị tyrimo tikslą. Atliekant tikslinę tiriamujų atranką, buvo laikomasi reikalavimo, kad visi tiriamieji teiktų skubiają medicinos pagalbą ne mažiau kaip vienerius metus.

Tyrimo metodai. Tyrimui buvo pasirinktas pusiau struktūrizuoto interviu metodas, kuriuo siekiama išsiaiškinti darbinès veiklos metu patiriamą riziką sveikatai. Tyrimo duomenys analizuoti turinio analizès metodu.

Rezultatai. Teikdami skubiąją medicinos pagalbą, slaugytojai susiduria su biologine, chemine, fizine, ergonomine ir psichosocialine rizika sveikatai. Tyrimas atskleide, kad slaugytojai, teikdami skubiosios medicinos pagalbos paslaugas, jaučia stresą, vidinę ịtampą bei baimę. Jie patiria smurtą, kūno sužalojimus, kaulų ir raumenų sistemos pokyčius, mikrotraumas aštriais instrumentais, riziką užsikrèsti ịvairiomis infekcinėmis ir neinfekcinemis ligomis, kurią lemia tiesioginis kontaktas su asmeniu, sąlytis su kūno skysčiais bei darbo metu naudojamų medikamentų poveikis. Slaugytojai patiria ir fizinès sveikatos pokyčius, tokius kaip bendras organizmo nuovargis, miego, skrandžio veiklos ar reprodukcinès sistemos sutrikimas, mitybos, medžiagu apykaitos, širdies ir kraujagyslių sistemos pakitimai. Psi- chinès sveikatos pablogèjimui įtakos turi dažna baimè, stresas bei atsiradusi vidinè įtampa.

\section{Ivadas}

Sveikatos priežiūros paslaugos yra viena iš darbo sričių, kurioje kyla didelis pavojus darbuotojo profesinei sveikatai ir saugai [10]. Slaugos profesija susijusi su daugybe biologinès, cheminès, fizinès ir psichosocialinès prigimties grèsmių, kurios ne tik daro neigiamą poveiki sveikatai, atsirandanti dèl profesinių ligų ir atsitikimų darbe, bet ir mažina slaugytojų darbo efektyvumą, arba sukelia klaidas darbo metu [7]. Pastaruoju metu plačiai diskutuojama apie stresorius, kuriuos patiria didelès rizikos profesijų atstovai, tačiau pavojus patirti kritinius įvykius bene dažniausias greitosios medicinos pagalbos stotyje dirbantiems sveikatos priežiūros specialistams. Skubiosios medicinos pagalbos personalo profesiniu sužalojimų rizika yra labai didelè, nes kasdieniame darbe jiems kyla daug pavojų [4,5]. Skubiosios pagalbos skyriai dirba ypač sunkiomis darbo aplinkos sąlygomis. Tai aplinka, kurioje patiriama daug streso, nes darbas yra spontaniškas, nenuspejjamas ir dažnai pavojingas $[1,2,8]$. Pagalba teikiama kelyje, pacientų namuose ir tokioje aplinkoje, kurioje reikalingi kūrybiški sveikatos problemų sprendimai, derinami su laiku ir tinkama priežiūra [2]. Skubiosios pagalbos darbuotojas gali paskirti ịprastinę ar neatidèliotiną paciento priežiūrą, arba skubiai reaguoti ịvykio vietoje, kad laiku suteiktų kritinę, gyvybę gelbstinčią pagalbą [2]. Kartotinis stresiniu įvykių, tokių kaip staigi mirtis, traumos, skausmas, gaivinimas, agresija ir smurtas, poveikis gali turèti neigiamos itakos darbuotojų fizinei, psichologinei ir emocinei sveikatai [1]. Skubiosios medicinos pagalbos teikimas yra labai rizikingas darbas, apimantis greitosios medicinos pagalbos greitkelio operacijas, sunkiujų i̇renginių vežimą, pacientų kèlimą ir gabenimą, sergančių ir ūmiai sužeistų asmenų būklès stabilizavimą tokiose vietose, kurios apibūdinamos kaip nekontroliuojamos [12]. Slaugytojai, teikiantys skubiają medicinos pagalbą, dirba nuolat besikeičiančioje aplinkoje su stresą patiriančiais pacientais ir jų artimaisiais [3,11], nereguliariu darbo laiku, blogomis fizinèmis sąlygomis, 
susiduria su žodinės ir fizinės prievartos rizika. Slaugytojai jaučia spaudimą, atsakomybės ir sunkių sprendimų riziką, triukšmingos aplinkos, streso, netinkamo elgesio apraiškas, riziką užsikrèsti infekcinėmis ligomis [11]. Su darbu susijusios stresinès reakcijos taip pat prisideda prie nevisavertiškos slaugos, o tai gali pakenkti pacientų saugai [6].

Tyrimo tikslas - atskleisti skubiosios medicinos pagalbos teikimo riziką slaugytojų sveikatai.

\section{Tyrimo medžiaga ir metodai}

Tiriamieji buvo parinkti atsižvelgiant ị tyrimo tikslą ir atliekant tikslingą atranką, laikantis reikalavimo, kad visi tiriamieji, teikiantys skubiąją medicinos pagalbą, būtų ją teikę ne mažiau kaip vienerius metus. Siekiant atskleisti skubiosios medicinos pagalbos teikimo riziką slaugytojų sveikatai, atliktas kokybinis tyrimas. Duomenų rinkimui pasirinktas pusiau struktūruoto interviu metodas. Naudota 12 iš anksto parengtų klausimų. Surinkti duomenys buvo transkribuojami ir analizuojami. Iš viso tyrime dalyvavo 15 skubiają medicinos pagalbą teikiančių slaugytojų. Tyrimo dalyviams užtikrintas anonimiškumas, duomenų analizès metu kiekvienam respondentui priskiriant kodą (nuo 1 iki 15). Tyrimas vyko $X$ greitosios medicinos pagalbos stotyje. Vidutinè pokalbio su tiriamaisiais trukmè -25 minutès, prieš tai suderinus susitikimo laiką.

\section{Tyrimo rezultatai}

Remiantis tyrimo dalyvių atsakymais, nustatyta, kad skubiosios medicinos pagalbos specialistai darbo metu susiduria su fiziniais, psichologiniais, ergonominiais, biologiniais ir cheminiais rizikos veiksniais, patiria fizinès ir psichinès sveikatos pokyčių.

Fiziniai rizikos veiksniai. Analizuojant interviu medžiagą su skubiają medicinos pagalbą teikiančiais slaugytojais, paaiškèjo, kad vienas iš fizinių sveikatos rizikos veiksnių yra naktinis darbas. Respondentai nurodè, kad būtent darbas naktimis lemia tam tikrus fizinius organizmo pokyčius. „, Tikrai sutrinka tas miego poilsio režimas ir paskui kartais sunku labai atbūt". „Nemiegojimas, tas pulsas dažnas būna, tai taip ir veikia manau, <...> “. „Jaučiamas nuovargis“. Slaugytojų teigimu, be fizinių organizmo pojūčių, darbas nakties metu mažina gebèjimą sukoncentruoti dèmesį. ,,Darbas naktimis, tai tas jau demesys nakti yra nebetoks, <...>. Tikrai reikia labai save suimti, $<\ldots>$, vien dèl tokio dèmesio, $<\ldots>$. Buvo toks atvejis, $\langle\ldots>$, ten moteris, $\langle\ldots>$, ir aš jos klausiu, ar šiuo metu pykina, kiek kartu vemète, kiek kartu viduriavote... ji man atsake tuos visus atsakymus ir aš supratau, kad aš po kurio laiko pamiršau, ka ji man sake,, tiesiog tas toksai dèmesys, tas nuovargis, padarè savo"; „,<..>, daugiau išsiblaškęs būni galbūt“. Remiantis tyrimo rezultatais, pastebèta, kad darbas nuo antros iki ketvirtos valandos nakties skubiosios pagalbos specialistams yra pats sunkiausias. „,Dirbti bütent sunkiausiai tai yra ryte, baigiant darba, kai tu esi atidirbęs para laiko ir jau tie paskutiniai kvietimai, ryte ypač, jie būna sunkūs labai “. Keičiasi ir bendravimas, nes nakties metu slaugytojai tylesni, dirglesni, piktesni, linkę mažiau kalbèti su pacientais ir jų artimaisiais: ,, Naktỉ būni dirglesnis žmogus, bent jau aš tai taip, nors žmogui tikrai reikalinga ta emocine pagalba, $\langle\ldots\rangle$, kartais net jauti neigiamas emocijas... “.

Kalbant su skubiosios medicinos pagalbos slaugytojais apie jų patiriamas traumas darbo metu, paaiškejjo, kad jie patiria ịvairius kūno sužalojimus. Vienas dažniausių sužalojimų yra darbo metu patiriamos įvairios traumos, kritimas ir (ar) slydimas: ,, $<$..>, esu turèjus trauma, kai žiemos metu važiavom ị seneliu globos namus, aš dejaau koja ant kilimèlio <...> ir jisai praslydo, ir aš gerokai esu susimušus kojos keli “. Avarijos, ištikusios kelyje, taip pat gali būti kūno sužalojimo priežastis. ,, <..> > Teko susidurti, prieš 3 metus, pakliuvom mes i avariją, važiavom 3 valanda nakties, važiavom pagrindine gatve su žiburèliais ir mumis nepraleido, $<\ldots>$, tai mes vertèmès, čiuožème, trenkèmés ị stulpq ir tik tada sustojome, <...>, lūžo šonkaulis vienas ir kairè koja buvo sumušta, kur liko liekamieji reiškiniai iki dabar, $<\ldots>$, matyt buvo ìtrūkęs raumuo, tai liko toks deformuotas šlaunies raumuo".

Analizuojant fizinius rizikos veiksnius sveikatai, atsiskleide dar vienas darbinès aplinkos rizikos veiksnys - užsikretimas įvairiomis ligomis. Dažniausiai pasitaiko kvèpavimo takų ligos. „,Kai yra žiema, tai labai padaugeja tu tokiu slogu, nes mes išeinam i kvietima, kvietimas yra lauke, pusiau apsirengęs, pusiau neapsirengęs, tai šilta, tai karšta, tai šalta, ir tikrai visokie kosuliai prasideda, sloga. <...>, sloga tikrai esu pasigavusi ir tikrai nuo darbo ". Teikiant skubiają medicinos pagalbą, galima užsikrèsti ir įvairiomis infekcinèmis ligomis: ,, $<\ldots>$, viena karta buvau roto virusa pasigavęs, bet greičiausiai iš to pačio paciento, nes maista valgèm su namiškiais ta pati" “.

Tyrimo duomenimis, prie skubiają medicinos pagalbą teikiančių slaugytojų fizinių sveikatos rizikos veiksnių priskirtinas darbo krūvio padidejimas, ypač - darbas paromis. „Sunku yra dirbti paromis, dažnai po dienos poilsio - vèl $i$ darbą; ,'Atrodo, kad gyveni tame darbe, nes namuose būni retai “. Padidejjęs kvietimų skaičius ir dažnesnis vykimas i ìvykio vietą didina darbo krūvị. ,, Naktị tenka dažniau keltis, nes lieka mažiau brigadu“. „Kai padaugeja kvietimu, ypatingai žiema pajaučiam didesnị krūvị".

Išanalizavus ir apibendrinus skubiosios medicinos pagalbos slaugytojų patirti galima teigti, kad jie susiduria su šiais fiziniais sveikatos rizikos veiksniais: naktinis darbas, kūno 
susižalojimai, užsikrètimas ịvairiomis ligomis bei padidèjęs darbo krūvis (1 lentelè).

Fizinės sveikatos pokyčiai. Interviu metu respondentai išsakè, kokius fizinès sveikatos pokyčius patiria teikdami skubiają medicinos pagalbą. Tyrimas parodè, kad slaugytojai, dirbantys $\mathrm{X}$ greitosios medicinos pagalbos įstaigoje, darbo metu patiria mitybos pokyčius. Vienas iš labiausiai akcentuojamų nusiskundimų yra valgymo ịpročių pasikeitimas. „,Kavos potraukis tai apskritai per 2 metus labai stipriai padidejo. $\langle\ldots>$, visas greitas maistas, $\langle\ldots>$. , Man darbo metu, taip norisi, kaip aš sakau, visokiu nesamoniu, o šiaip tai, ne visada pavyksta pavalgyti, <... . Mitybos pokyčiams turi įtakos ir apetito padidejimas. „,Apetitas padideja, $<\ldots>$, ir po darbo, ir prieš darba, ir darbe, aš visa laika alkana būnu praktiškai“. „Didesnis alkio jausmas“.

Respondentai, kalbėdami apie savo sveikatą, išsakè atsiradusius miego pokyčius. Nekokybiškas miegas nurodomas kaip vienas iš aspektų, lemiančių miego sutrikimus. ,,Miego

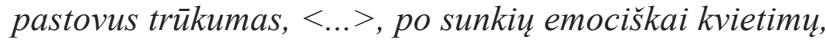
tikrai labai tai ịtakoja miego kokybę“. „Kad išsiderini, vis tiek išsibalansuoja tas visas miego ritmas ir, jeigu išsimiegi diena, tai paskui nemiegi naktị ir atvirkčiai“. „, <..>. Tas miegas nera toks gilus ". Analizuojant, kokius miego sutrikimus slaugytojai patiria, išaiškejjo nemiga. ,, Kaip ir nemiga atsiranda“. „, Kartais aš po sunkios darbo paros negaliu užmigti ". Greta nemigos ir nekokybiško miego, slaugytojus vargina mieguistumas. „, Kaip užmušta miegi, ten kur stovi arba sèdi“. „Jeigu tokia ramesnè para, tai aš dabar, kaip aš sakau - aš galiu netgi stoveddama miegot, man visiškai néra problemu, kur miegot, ko anksčiau taip nebūdavo ".

Tyrimo duomenimis, respondentai skundèsi ir bendru organizmo nuovargiu. ,,Jaučiasi labai didelis nuovargis, silpna ir labai norisi miegot, ir miegot, ir miegot". „, Tai tas pastovus nuovargis , <..>, kartais silpnumas“.

Tyrimas atskleide, kad slaugytojai patiria širdies ir kraujagyslių sistemos sutrikimus, pasireiškiančius širdies susitraukimų dažnio pokyčiais bei ekstrasistolių atsiradimu. „, Atsiranda tachikardija “. , Man pagrinde tas ritmas, ekstrasistoliu labai dang atsirado, ir dabar, po kiekvieno tokio streso, gal jaučiu dangiau tokị širdies plakima “. Dèl darbo specifikos slaugytojams pasireiškè ir arterinio kraujospūdžio pokyčių, sukèlusių skausmą pakaušio srityje. ,,Spaudimo tas

1 lentelè. Fizinių rizikos veiksnių įtaka sveikatai

\begin{tabular}{|c|c|c|c|}
\hline Kategorija & $\begin{array}{l}\text { Subkate- } \\
\text { gorija }\end{array}$ & $\mathbf{N}$ & Patvirtinantys teiginiai \\
\hline \multirow[t]{3}{*}{$\begin{array}{l}\text { D a r b a s } \\
\text { n a k t i e s } \\
\text { metu }\end{array}$} & $\begin{array}{l}\text { Dèmesio kon- } \\
\text { centracijos } \\
\text { sumažejimas }\end{array}$ & 15 & 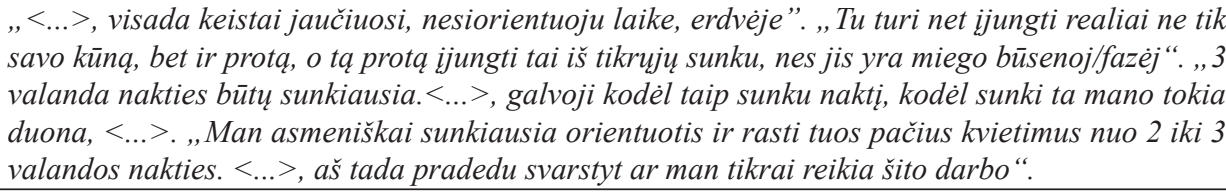 \\
\hline & $\begin{array}{l}\text { Fiziniai } \\
\text { organizmo } \\
\text { pokyčiai }\end{array}$ & 10 & 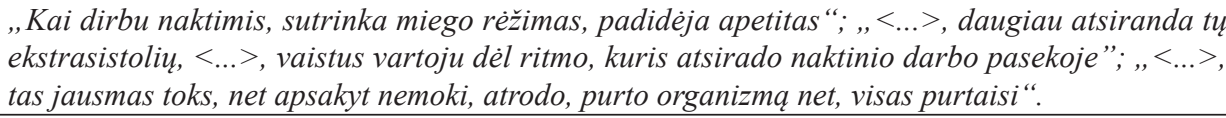 \\
\hline & $\begin{array}{l}\text { Bendravimo } \\
\text { pokyčiai }\end{array}$ & 6 & 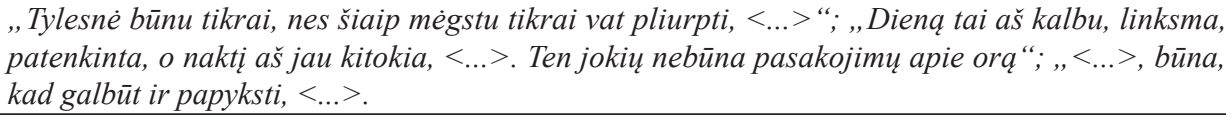 \\
\hline \multirow[t]{2}{*}{$\begin{array}{l}\text { Kūno susi- } \\
\text { žalojimai }\end{array}$} & $\begin{array}{l}\text { Traumos, } \\
\text { kritimas, } \\
\text { slydimas }\end{array}$ & 9 & 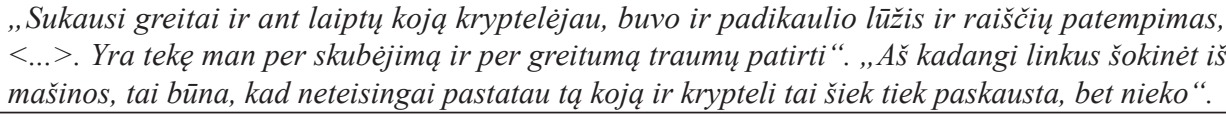 \\
\hline & $\begin{array}{l}\text { Avarijos } \\
\text { kelyje }\end{array}$ & 5 & $\begin{array}{l}\text { „Autoịvykis yra buvęs, }<\ldots>\text {, net stacionare buvau gydyta, nes patyriau galvos trauma... “. „Buvau } \\
\text { buvau, }<\ldots>\text { mes stovejome kelkraštyje, teikeme pagalba ir tuo metu, kol mes dirbome automobilyje } \\
-i \text { mus atsitrenké, }<\ldots>\text { “. }\end{array}$ \\
\hline \multirow{2}{*}{$\begin{array}{l}\text { Užsikrèti- } \\
\text { mas îvai- } \\
\text { riomis li- } \\
\text { gomis }\end{array}$} & $\begin{array}{l}\text { Neinfekcinès } \\
\text { ligos }\end{array}$ & 6 & 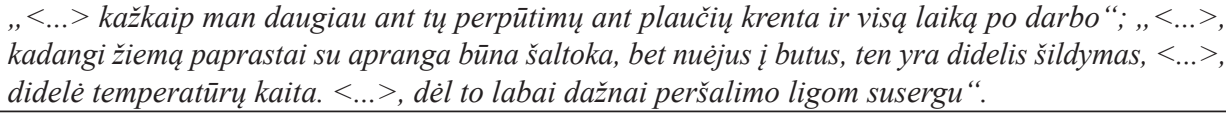 \\
\hline & $\begin{array}{l}\text { Infekcinès } \\
\text { ligos }\end{array}$ & 1 & 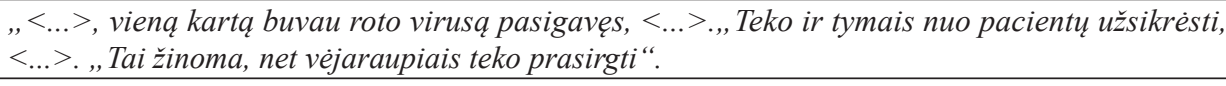 \\
\hline \multirow{2}{*}{$\begin{array}{l}\text { P a d i d è - } \\
\text { jęs darbo } \\
\text { krūvis }\end{array}$} & \begin{tabular}{c|} 
Darbas \\
paromis
\end{tabular} & 3 & $\begin{array}{l}\text { „Sunku yra dirbti paromis, dažnai po dienos poilsio - vèl ị darba“;; „Mes dirbam dideliu krūviu, } \\
\text { tai va, nes dažnas dirba po } 24 \text { valandas“. }\end{array}$ \\
\hline & $\begin{array}{c}\text { Dažnesnis } \\
\text { išvykimas pa- } \\
\text { gal kvietimus }\end{array}$ & 2 & $\begin{array}{l}\text { „Naktị tenka dažniau keltis, nes lieka mažiau brigadu“. „, Kai padaugèja kvietimu, ypatingai žiema } \\
\text { pajaučiam didesnị krūvì“. ,, Nakties metu mūsu lieka mažiau, o kvietimu tai daug, kartais nespèji } \\
\text { sugrǐžti, o jau vèl kviečia“. }\end{array}$ \\
\hline
\end{tabular}


šokinèjimas, $<\ldots>$, ir man ypatingai vat vakarais büna, kad nu jaučiu pakauši taip skauda, spazmuoja“.

Analizuojant rizikos veiksnius sveikatai, respondentai išsakè, kad patiria medžiagų apykaitos pokyčių, pasireiškiančių sulètejjusia medžiagų apykaita (, Labai sulètėjo, labai iš tikrujų sulètèjo, bet vèl galbūt dar tas ịtakoja, kad mažai vandens geriu“. „Naktinis darbas, $\langle\ldots>$, tai išbalansuoja visa organizma, visa absoliučiai"), skrandžio veiklos sutrikimų, pasireiškiančių skrandžio rūgštingumo padidẻjimu $(,,<\ldots>$, atsirado bèdu su skrandžiu, $<\ldots>$, büna tu simptomu, būna jie kartais ir miegot trukdo. Dèl padidejusio rūgštingumo, $<\ldots>$, tai va tokie dalykai, tos rūgštys visokios ir atsirado ir jos büna ypač kankina naktị") ir menstruacinio ciklo pokyčių (,, Aš manau, kad ịtakoja, ir tasai darbas, nes bütent tasai ciklas tampa nebe reguliarus, išsibalansuoja ta prasme, nebera to tokio ciklo normalaus "). Apžvelgus respondentų pasisakymus, galima teigti, kad skubiosios medicinos pagalbos slaugytojai susiduria su šiais fizinès sveikatos pokyčiais: miego sutrikimai, mitybos pokyčiai, medžiagų apykaitos pokyčiai, skrandžio veiklos sutrikimas, reprodukcinès sistemos sutrikimai, širdies ir kraujagyslių sistemos pokyčiai ir bendras organizmo nuovargis (2 lentelè).

Psichologiniai rizikos veiksniai. Atsižvelgiant ị tiriamujų pasisakymus, vienas iš dažniausių skubiosios medicinos pagalbos slaugytojų psichologinès rizikos veiksnių sveikatai yra baimè. Dažniausiai slaugytojai bijo užsikrèsti ir (ar) susirgti infekcine ar neinfekcine liga. ,, Galbūt, kai buvo tasai tymu protrūkis <...>. Būtent tuo metu jau jau-

2 lentelè. Slaugytojų fizinès sveikatos pokyčiai

\begin{tabular}{|c|c|c|c|}
\hline Kategorija & $\begin{array}{c}\text { Subkate- } \\
\text { gorija }\end{array}$ & $\mathbf{N}$ & Patvirtinantys teiginiai \\
\hline \multirow[t]{2}{*}{$\begin{array}{l}\text { Mitybos } \\
\text { pokyčiai }\end{array}$} & $\begin{array}{l}\text { Valgymo } \\
\text { ipročių pasi- } \\
\text { keitimas }\end{array}$ & 9 & $\begin{array}{l}\text { „Būtent tas ir pasireiškia, kad tai būtų saldumynai arba kažkoks greitas maistas, }<\ldots>\text {.. Nepavalgai } \\
\text { nieko norimu laiku“. „Po paros dažniausiai norisi nesveiko maisto, to greito, kaip sakant. }\end{array}$ \\
\hline & $\begin{array}{l}\text { Apetito padi- } \\
\text { dejjimas }\end{array}$ & 5 & $\begin{array}{l}\text { „Labai padideja apetitas, aš manau, kad dèl to energijos trūkumo, jis bando kompensuoti maistu, } \\
\text { nes realiai valgai visokias nesąmones “. „, Gal aš kaip tik tokia, aš iš tokiu streso atveju daugiau } \\
\text { valgau, <...>“. }\end{array}$ \\
\hline \multirow[t]{3}{*}{$\begin{array}{l}\text { Miego su- } \\
\text { trikimai }\end{array}$} & $\begin{array}{l}\text { Nekokybiš- } \\
\text { kas miegas }\end{array}$ & 6 & $\begin{array}{l}\text { „Grižęs iš darbo pamiegi, tai aš atsikeldavau kaip kvaila tokia, kaip apdujus tokia“; „, , ..>, tas } \\
\text { toksai miego nebuvimas gaunasi, būna, kad tu grị̌ti nuvargęs po tos paros, jinai buvo visiškai } \\
\text { bemiegè, bet tu iš to nuovargio net negali užmigt". }\end{array}$ \\
\hline & Nemiga & 5 & $\begin{array}{l}\text { „Atsiranda toks vartymasis, nemiga“. „Ir ta nemiga, jinai tkrai kamuoja, ypatingai po sunkiu } \\
\text { emociškai kvietimu“. }\end{array}$ \\
\hline & $\begin{array}{l}\text { Mieguistu- } \\
\text { mas }\end{array}$ & 2 & $\begin{array}{l}\text { „Kaip užmušta miegi, ten kur stovi arba sèdi“. „,Jeigu tokia ramesnè para, tai aš dabar galiu netgi } \\
\text { stovèdama miegot, man visiškai nèra problemu, kur miegot, ko anksčiau taip nebūdavo“. }\end{array}$ \\
\hline \begin{tabular}{l|} 
Bendras \\
organizmo \\
nuovargis
\end{tabular} & $\begin{array}{l}\text { Dažnas } \\
\text { nuovargis }\end{array}$ & 5 & $\begin{array}{l}\text { „Nu šiaip, kai tu jauti toki pastoviai nuovargi, silpnuma, jëgu neturejima“". „Be abejo, jaučiu nuo- } \\
\text { vargi darbo metu, jeigu darbo labai daug ir po darbo - taip. „Po paros yra nuovargis, nes reikia } \\
\text { sekančios paros, kad atsigautum“. }\end{array}$ \\
\hline \multirow[t]{2}{*}{$\begin{array}{l}\text { Širdies ir } \\
\text { krauja- } \\
\text { gyslių } \\
\text { sistemos } \\
\text { pokyčiai }\end{array}$} & $\begin{array}{c}\text { Širdies } \\
\text { susitrau- } \\
\text { kimų dažnio } \\
\text { pokyčiai } \\
\end{array}$ & 4 & $\begin{array}{l}\text { „Atsiranda tachikardija“. „, Man pagrinde tas ritmas, ekstrasistolių labai daug atsirado, ir dabar, po } \\
\text { kiekvieno tokio streso, gal jaučiu daugiau tokị širdies plakimą“. „Permušimu būna , kartais pajaučiu“. }\end{array}$ \\
\hline & \begin{tabular}{c|} 
Arterinio \\
kraujospū- \\
džio pokyčiai
\end{tabular} & 1 & 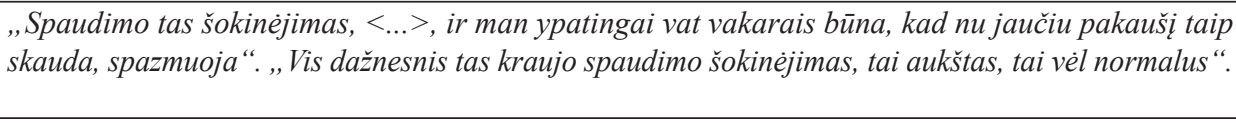 \\
\hline $\begin{array}{l}\text { Medžiagų } \\
\text { apykaitos } \\
\text { pokyčiai }\end{array}$ & $\begin{array}{c}\text { Sulètejusi } \\
\text { medžiagų } \\
\text { apykaita }\end{array}$ & 3 & $\begin{array}{l}\text { „Labai iš tikrujuc sulètejo, bet vèl, galbūt, dar tas ịtakoja, kad mažai vandens geriu“; , ,<...>. Ir } \\
\text { svoris priaugo ir visa kita, nors iki to - to nebuvo“. }\end{array}$ \\
\hline $\begin{array}{l}\text { Skrandžio } \\
\text { veiklos su- } \\
\text { trikimas }\end{array}$ & $\begin{array}{l}\text { Skrandžio } \\
\text { rūgštingumo } \\
\text { padidejimas }\end{array}$ & 1 & $\begin{array}{l}\text { „Tikrai atsirado bédu su skrandžiu }<\ldots>\text {, büna tú simptomu, büna jie kartais ir miegot trukdo. Dèl } \\
\text { padidejusio rūgštingumo, }<\ldots>\text {, tos rūgštys visokios ir atsirado ir jos ypač kankina nakti “. }\end{array}$ \\
\hline $\begin{array}{l}\text { Repro- } \\
\text { dukcinės } \\
\text { sistemos } \\
\text { sutrikimai } \\
\end{array}$ & $\begin{array}{l}\text { Menstrua- } \\
\text { cijų ciklo } \\
\text { pokyčiai }\end{array}$ & 1 & $\begin{array}{l}\text { „Aš manau, kad ịtakoja, ir tasai darbas, nes bütent tasai ciklas tampa nebe reguliarus, išsibalan- } \\
\text { suoja ta prasme, nebera to tokio ciklo normalaus “. }\end{array}$ \\
\hline
\end{tabular}




\section{4}

čiau, $<\ldots>$, nerima toki vidini “ „, $<\ldots>$, meningokoko baimè yra visa laika, difterijos baime yra, <...> “. „Tai visa laika bijai, kad kažka tai gali pasigauti, užsikrèsti “. Baimès atsiradimui itakos turi ir darbo metu patiriamas fizinis ir (ar) psichologinis smurtas: , < _. > staiga jinai mane stveré. Tai liko tik tiek, <...>, kad nuo nagu tos žymès, tokios žaizdos ant kaklo, <...>. Inai griebe už kasos surištos ir taip per dekoltè čia visa, už rūbu užsikabino"; , ,<...>, koliojimai visi, arba, pavyzdžiui, įvertinimas išsilavinimo, ten slaugytojo, tai čia ne gydytoja tu, nieko nemoki, nieko nesupranti, tai gal va tokie vat labiau isimena". Respondentų teigimu, darbo metu išgirstas pavojaus signalas taip pat sukelia tam tikrą organizmo reakciją: ,, <..> > kažkaip emocijos tiktai aplanko po to. Galbūt kažkoks tai viduj išgyvenimas, galbūt pra- deda širdis kažkaip plakti labiau“; ,,nu kažkiek tai, kažkaip padažnindavo ta širdies ritma, $<\ldots>$, būna, būna ir dabar tu drebuliu, visko būna, žiürint ka perskaitai “. Vykstant ị ivykio vietą, pas pacientą, svarbus greitas reagavimas, todèl padidejja avarijų rizika. Slaugytojai nurodo, kad jaučia baimę patirti eismo ịvykị: ,, < ..>, nu vis tiek dabar kažkaip, baime tokia atsiradus, <...>. Jau ta baimè yra, ko anksčiau nebuvo“. „, Tiesiog nu kartais važiuoji ir tu galvoji, kad iš betkur betkas gali išlịsti, užkišti, atsitrenkti “.

Teikdami skubiają medicinos pagalbą, slaugytojai neišvengiamai susiduria su stresinėmis situacijomis. Dažnai patiriamas stresas sukelia sveikatos sutrikimus, lemiančius ivvairius organizmo negalavimus. ,,Esu sirgus ir onkologine liga, <...>. Gydytojai sako, kad tai įtakojo darbas naktimis,

3 lentelè. Psichologinių rizikos veiksnių įtaka sveikatai

\begin{tabular}{|c|c|c|c|}
\hline $\begin{array}{l}\text { Kate - } \\
\text { gorija }\end{array}$ & $\begin{array}{l}\text { Subkate- } \\
\text { gorija }\end{array}$ & $\mathbf{N}$ & Patvirtinantys teiginiai \\
\hline \multirow[t]{5}{*}{ Baimè } & $\begin{array}{l}\text { Baimè užsi- } \\
\text { krèsti ir (ar) } \\
\text { susirgti tam } \\
\text { tikra liga }\end{array}$ & 15 & 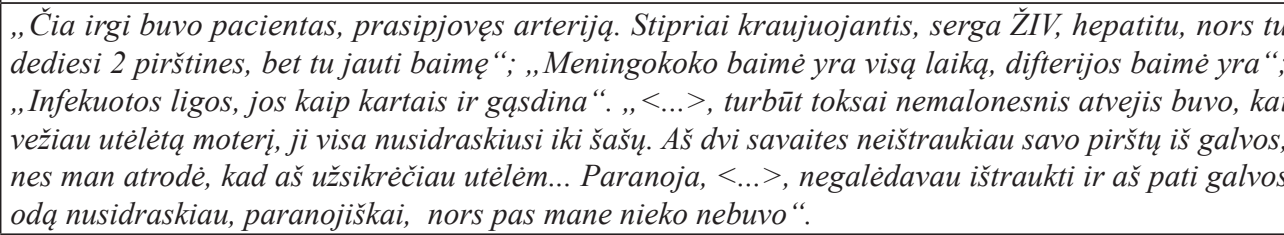 \\
\hline & $\begin{array}{l}\text { Baimè patirti } \\
\text { psichologini } \\
\text { smurtą }\end{array}$ & 9 & $\begin{array}{l}\text { „Koliojimai visi, arba, pavyzdžiui, ìvertinimas išsilavinimo, ten slaugytoja, tai čia ne gydytoja tu, } \\
\text { nieko nemoki, nieko nesupranti, tai gal tokie vat labiau ìsimena “; ,, Tas psichologinis smurtas, kai an } \\
\text { tavęs rèkia, tie pacientai. <...>, spaudimas iš tu artimuju, iš to ligonio, tai jisai praktiškai kiekienam } \\
\text { kvietime yra“. }\end{array}$ \\
\hline & $\begin{array}{l}\text { Baimè patirti } \\
\text { fizinị smurtą }\end{array}$ & 6 & 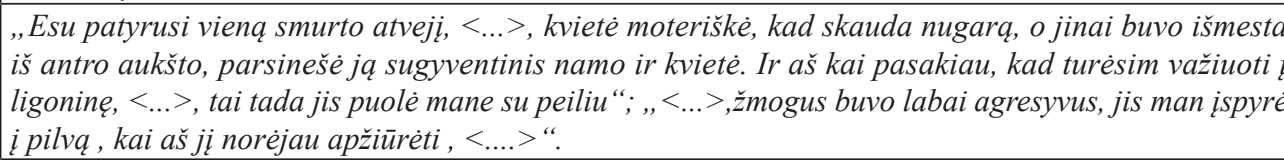 \\
\hline & $\begin{array}{l}\text { Baimè, išgir- } \\
\text { dus pavojaus } \\
\text { signalą }\end{array}$ & 9 & 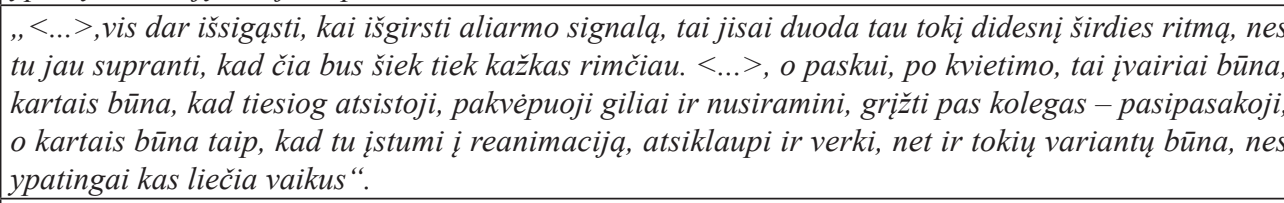 \\
\hline & $\begin{array}{l}\text { Baimè patirti } \\
\text { eismo ịvykị }\end{array}$ & 5 & $\begin{array}{l}\text { „Atsiranda tụ baimiu, tu psichologiniu, kai tu leki, tau kažkas tai atsitinka, kažkokia tai trauma, ta } \\
\text { tu ta karta lyg ir bijai iš tikruju greitai lèkti“., „Dabar aš bijau važiuoti - išlikusi ta tokia baime, nor } \\
\text { daugiau lygtais įsikabinti, vis tiek segamès diržus“. }\end{array}$ \\
\hline \multirow[t]{2}{*}{ Stresas } & $\begin{array}{l}\text { Streso ịtaka } \\
\text { bendrai orga- } \\
\text { nizmo būklei }\end{array}$ & 10 & 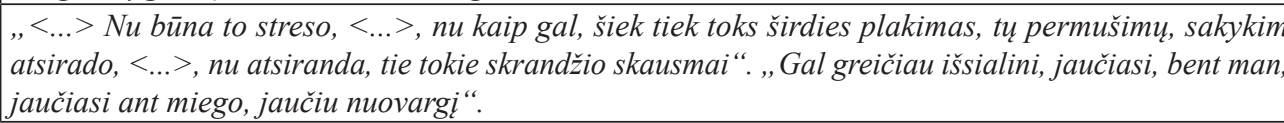 \\
\hline & $\begin{array}{l}\text { Streso ịtaka } \\
\text { sužinojus } \\
\text { apie kvietimo } \\
\text { specifiškumą }\end{array}$ & 4 & $\begin{array}{l}\text { „, }<\ldots>\text {, kelia viskas, kas yra susije su vaikais ir su néštumu. }<\ldots>\text {, paskui dar trečias yra dūstantys } \\
\text { žmonès “. „, Visada mes labiausiai vaiku bijom, jeigu tai va yra trauminiai rimti kvietimai, }<\ldots . .>\text {, vaiko } \\
\text { gaivinimas koks nors būtu, tai čia kiekvieno košmaras“. }\end{array}$ \\
\hline $\begin{array}{l}\text { Vidinė } \\
\text { ịtampa }\end{array}$ & $\begin{array}{l}\text { Varginančių } \\
\text { minčių atsira- } \\
\text { dimas }\end{array}$ & 9 & $\begin{array}{l}\text { „Tai manau, tu vis tiek dèl to paciento pergyveni }<. .>\text {, tu darbo nepamiršti, vis galvoji ir galvoji“" } \\
\text { „Po darbo kartais pradedi galvoti apie kai kuriuos pacientus, vis tiek yra tokiu, kurie istringa, kur } \\
\text { pradedi analizuoti ar padarei viska tikrai taip, kaip reikejjo ar tikrai ta tavo pagalba buvo tikslinga ir } \\
\text { veiksminga“. , Kartais büna taip, kad tu istumi i reanimacija, atsiklaupi ir verki, net ir tokiu variant! } \\
\text { büna, }<\ldots . .>\text {. }\end{array}$ \\
\hline
\end{tabular}


stresas va“. „Man, pavyzdžiui, pradèjo spaudimas šokinèti. Ne tai, kad isai pastoviai ten, bet büna kelis kartus i savaite jis man užkyla, ten nukrenta, būna tachikardijos priepuoliai, anemija lygiai taip pat, kartas nuo karto atsinaujina, bet visa tai ịtakoja stresas ". Remiantis respondentų atsakymais, kvietimo specifiškumas taip pat sukelia stresą. ,, Kvietimai pas vaikus arba ịvairūs gaivinimai, sunkūs kvietimai, kur galbūt nepavyksta išgelbèt gyvybès ar klinikinè mirtis ivyksta prie mano akiu“.. „, Galbūt vaikai, nes yra tokia va nežinomybè, su tais vaikais yra sunkiau, jeigu kažkokia nelaime atsitinka, $<\ldots>$, yra toks kitoks tas jausmas, kai važiuoji pas suaugusijj ir, kai važiuoji pas vaika“".

Respondentai išsakè, kad sudètingos darbinès situacijos, patiriamos teikiant skubiajją medicinos pagalbą, sukelia vidinę ittampą. Nuolatinis galvojimas apie jas lemia varginančiu minčių atsiradimą. , Būna, kad neapleidžia ten tas galvoji, bet stengiesi kažkaip su tuo susidoroti“. „,Tai manau, tu vis tiek dèl to paciento pergyveni. Kažkaip tu vis dar apie ji galvoji, tu, kad ir grịžti namo, tu darbo nepamiršti “.

Viena informantè nurodè jaučianti liūdesio atsiradimą, kuris pasireiškia verksmu esant tam tikroms sudetingoms situacijoms darbo metu. „Pasipasakoji, o kartais būna taip, kad tu istumi i reanimacija, atsiklaupi ir verki, net ir tokiu variantu būna, <...>. Vaikai tai čia visa laika bus ir yra skaudžiausia dalis. Tai vat vienas toks ir kvietimas buvo, kad turejjau neišnešiotukus. $<\ldots>$, aš visa laika šnekejjau, teikiau pagalba ir kalbejjau su tuo trinkančiu kvépavimu kūdikèliu, ir atsimenu labai puikiai, kad aš ìstūmiau i reanimacija, atsitūpiau ir nuo širdies apsiverkiau, nes tai buvo pats baisiausias kvietimas.

Apibendrinant galima teigti, kad skubiosios medicinos pagalbos specialistai darbo metu susiduria su šiais psichologiniais sveikatos rizikos veiksniais: baimè, stresas, vidinè itampa (3 lentelè).

Ergonominiai rizikos veiksniai. Slaugytojų buvo klausiama apie darbe patiriamų ergonominių veiksnių įtaką jų kaulų ir raumenų sistemai. Remiantis apklaustujų atsakymais, dažniausia problema, atsirandanti dèl pacientų kèlimo ir nešimo - stuburo skausmas: ,, $<\ldots>$, nugaros juosmens skausmai, <...>. Atsirado eigoje, kaip radikulopatijos skausmai, nežinau nesityriau, panaudoji ten priešuždegiminius ir viskas, tepalai ir viskas ". Kai kurie slaugytojai po budèjimo ar sunkesnio paciento transportavimo jaučia viso kūno raumenu skausmą. ,, Po paros visa laika jaučiuosi kaip po sporto klubo. Visa laika“. „Ir kèlimo metu būna, arba tiesiog kada pavargsti, pareini po budejjimo ir taip kojas, raumenis skauda. Būna kèlimo metu skauda ir būna po budejimo tuos raumenis skauda - nugaros, koju“. Viena informantė nu-

4 lentelė. Ergonominių rizikos veiksnių įtaka sveikatai

\begin{tabular}{|c|c|c|c|}
\hline $\begin{array}{l}\text { Katego- } \\
\text { rija }\end{array}$ & $\begin{array}{c}\text { Subkate- } \\
\text { gorija }\end{array}$ & $\mathbf{N}$ & Patvirtinantys teiginiai \\
\hline \multirow{4}{*}{$\begin{array}{l}\text { Kaulų ir } \\
\text { rau- } \\
\text { menų } \\
\text { sistemos } \\
\text { pokyčiai }\end{array}$} & $\begin{array}{c}\text { Stuburo } \\
\text { skausmas }\end{array}$ & 10 & $\begin{array}{l}\text { „Stuburas ir kupra auga, kaip aš sakau. Taip, yra problemu su stuburu - ir skauda, ir krypsta tas stuburas. } \\
\text { Skausmai ne nuolatiniai, gal daugiau po kokio fizinio krūvio, kai tenka kelti, tai va po to atsiliepia, }<\ldots>\text {; } \\
\text { „, <...>, fizinis darbas, pacientu nešimas ịtakoja nugaros skausmus, }<\ldots>\text {, dažniausiai po tu visu nešimu, man } \\
\text { tikrai skauda, būna reikia, kad ir vaistus leistis“. }\end{array}$ \\
\hline & $\begin{array}{l}\text { Viso kūno } \\
\text { raumenų } \\
\text { skausmas }\end{array}$ & 2 & $\begin{array}{l}\text { „Po paros visa laika jaučiuosi kaip po sporto klubo“. „Ir kèlimo metu būna, arba tiesiog kada pavargsti, pareini } \\
\text { po budèjimo ir taip kojas, raumenis skauda. Büna kèlimo metu skauda, ir büna po budèjimo tuos raumenis } \\
\text { skauda-nugaros, kojü. }\end{array}$ \\
\hline & \begin{tabular}{c|c} 
Kaklo \\
raumenų \\
skausmas
\end{tabular} & 1 & $\begin{array}{l}\text { „Man yra išvaržos kakle, užspaudžia ranka, <... >. Kaklo skausmas dabar yra } 4 \text { metai, kai tos išvaržos, tai } \\
\text { man ị metus viena karta reikia reabilitacijos. Pagrinde kaklas, pilvo preso skausma jaučiu retkarčiais, jeigu } \\
\text { tampau sunkiau }<\ldots>\text {. }\end{array}$ \\
\hline & $\begin{array}{c}\text { Rankų } \\
\text { raumenų } \\
\text { skausmas }\end{array}$ & 1 & $\begin{array}{l}\text { „Nu nešti kai reikia, va dabar nešèm, tai skauda kairę ranka ties alkūne, kai reikia nešti tai tempia, <... >, kairès } \\
\text { rankos, pasikartojantys vis, patempi, tai vat tada jaučiu kairę ranka nuo alkūnès, tiesiog nuo judesio, reiškia } \\
\text { yra kažkoks tai patempimas“. }\end{array}$ \\
\hline
\end{tabular}

5 lentelè. Biologinių rizikos veiksnių įtaka sveikatai

\begin{tabular}{|c|c|c|}
\hline Kategorija & $\mathbf{N}$ & Patvirtinantys teiginiai \\
\hline $\begin{array}{l}\text { Mikrotraumos } \\
\text { aštriais instru- } \\
\text { mentais }\end{array}$ & 8 & 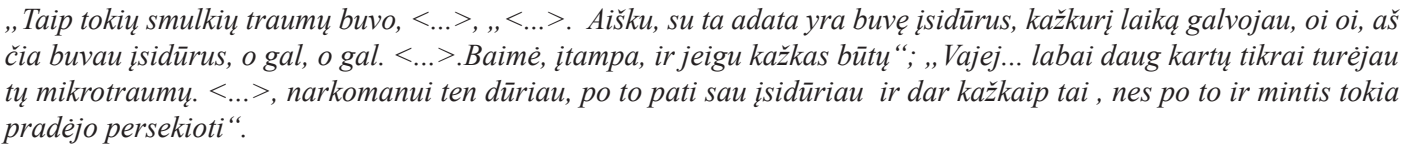 \\
\hline $\begin{array}{l}\text { Sąlytis su } \\
\text { kūno skysčiais }\end{array}$ & 2 & $\begin{array}{l}\text { „Nu yra buvę, kad kvietimai tokie, kad vos neišsimaudai kraujuose, ir, pavyzdžiui, tu nusiimi pirštines ir tu matai, } \\
\text { kad tavo pirštinès, jos néra suplyšusios, bet rankos kruvinos likę ir nesupranti, per viršu va “; ,, <..., su pirštinèm } \\
\text { visa laika, bet pirštinés tikrai ir suplyšta }<\ldots>\text {, tai visq laika tada aš ten plaunuosi, tas rankas, dezinfekuoju ir žodžiu } \\
\text { visaip kitaip saugausi“.. }\end{array}$ \\
\hline
\end{tabular}


rodè, kad kaulų ir raumenų sistemos pokyčiai jai pasireiškia skausmu kaklo srityje, dèl kurio reikia reabilitacijos. ,, Man yra išvaržos kakle, užspaudžia ranka, <...>. Pagrinde kaklas, pilvo preso skausma jaučiu retkarčiais, jeigu tampau sunkiau $<\ldots>$ ". Dèl dažno pacientų nešimo atsiranda ir rankų skausmas. „Nu nešti kai reikia, va dabar nešèm tai skauda kairę ranka ties alkūne, kai reikia nešti, tai tempia, $<\ldots>$, kaires rankos, pasikartojantys vis, patempi, tai vat tada jaučiu kairę ranką nuo alkūnès, tiesiog nuo judesio, reiškia yra kažkoks tai patempimas".

Išanalizavus respondentų atsakymus, galima teigti, kad ergonominiai rizikos veiksniai sukelia šiuos kaulų ir raumenų sistemos pokyčius: stuburo skausmą, viso kūno raumenų skausmą, kaklo raumenų skausmą, rankų raumenų skausmą. Visus šiuos pokyčius sukelia netaisyklinga kūno padètis kèlimo ir nešimo metu (4 lentelè).

Biologiniai rizikos veiksniai. Vienas iš dažniausiai pasitaikančių biologinių rizikos veiksnių, su kuriais susiduria skubiosios medicinos pagalbos slaugytojai, yra mikrotraumos aštriais instrumentais (,, < ..>, nu yra tekę įsidurti su glikemijos adatèle, bet aš saugau save, stengiuosi, ir taip nèra, kad dažnai issidurtum, galima čia ant ranku pirštu suskaičiuot, kiek yra buvę. <...>, kaip jaučiuosi, nu tai atrodo va velnias isidūriau“) ir sąlytis su kūno skysčiais (,,Nu yra buvę, kad kvietimai tokie, kad vos neišsimaudai kraujuose, ir, pavyzdžiui, tu nusiimi pirštines, ir tu matai, kad tavo pirštinès, jos néra suplyšusios, bet rankos kruvinos likę ir nesupranti, per viršu va "; ,, < ..>, su pirštinèm visq laika, bet pirštinès tikrai ir suplyšta, <..>, tai visa laika tada aš plaunuosi, tas rankas, dezinfekuoju ir žodžiu visaip kitaip saugausi “) (5 lentelè).

Cheminiai rizikos veiksniai. Kalbant apie asmens sveikatos priežiūros ịstaigoje dažniausiai naudojamas chemines medžiagas, išaiškèjo, kad slaugytojai dažniausiai susiduria su dezinfekantais bei dezinfekantais ir aerozoliais. Šios daž- nai darbe naudojamos cheminès medžiagos darbuotojams sukelia tam tikrus odos pažeidimus (,O žiema, tai sureaguoja oda i sausejjima, tai nuo dezinfekanto ranku, bet čia tiktai žiema pastebejau“; „,Turbūt dezinfekantas daugiausiai toksai cheminis, kuris reaguoja su mano oda, nes man iš karto šerpetoja rankos “) ir kvejpavimo takų dirginimą (,, Tie purškalai gal kažkiek, tie aerozoliai, papurški, tai sudirgina kvepavimo takus").

Slaugytojai pasakè, kad vienkartinių pirštinių mūvèjimas jiems sukelia rankų alergiją. ,,Anksčiau buvo tokios pirštinès, $k u r<\ldots>$, jausdavau alergija, $<\ldots>$, iki dabar sunku pritaikyti, kas tinka“.

Analizuojant priemones, kurių sudètyje yra cheminių medžiagų, pastebėta, kad darbo metu naudojami medikamentai taip pat gali sukelti alerginę reakciją. ,,Aš asmeniškai atkreipiau dèmesĭ, kad man diazepamas, ampulès raminančiy man netinka, aš kai ja sutraukiu ị švirkšta, man paraudonuoja veidas. <...>. Aš tiesiog, kaip atrodo, patinstu biški “ (6 lentelè).

\section{Išvados}

1. Teikdami skubiąą medicinos pagalbą, slaugytojai susiduria su fiziniais, psichologiniais, ergonominiais, biologiniais bei cheminiais rizikos veiksniais. Šie veiksniai daro neigiamą poveikị jų sveikatai, sukeldami ịvairius fizinius ir psichologinius sveikatos sutrikimus, ligas ir nelaimingus atsitikimus darbe.

2. Tyrimas atskleidè, kad slaugytojai jaučia šiuos fizinès sveikatos pokyčius: miego sutrikimus, mitybos ir medžiagu apykaitos pokyčius, skrandžio veiklos ir reprodukcinès sistemos sutrikimus, širdies ir kraujagyslių sistemos pokyčius bei bendrą organizmo nuovargi. Psichinès sveikatos pokyčiams priskiria baimès, streso ir vidinès įtampos atsiradimą.

6 lentelė. Cheminių rizikos veiksnių įtaka sveikatai

\begin{tabular}{|c|c|c|c|}
\hline Kategorija & Subkategorija & $\mathbf{N}$ & Patvirtinantys teiginiai \\
\hline \multirow{2}{*}{$\begin{array}{l}\text { Dezinfekan- } \\
\text { tai, dezinfe- } \\
\text { kantai- } \\
\text { aerozoliai }\end{array}$} & $\begin{array}{l}\text { Odos pažeidi- } \\
\text { mas }\end{array}$ & 3 & 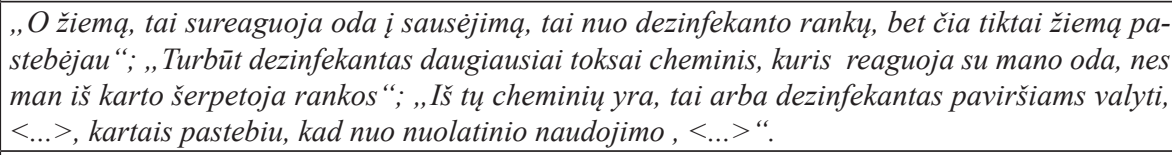 \\
\hline & $\begin{array}{l}\text { Kvèpavimo } \\
\text { takų dirginimas }\end{array}$ & 1 & „Tie purškalai gal kažkiek, tie aerozoliai, papurški, tai sudirgina kvépavimo takus. \\
\hline \multirow{2}{*}{$\begin{array}{l}\text { Vienkartinès } \\
\text { pirštinès }\end{array}$} & Alergija & 1 & $\begin{array}{l}\text { „Anksčiau buvo tokios pirštinès, } k u r<\ldots>\text { jausdavau alergija, }<\ldots>\text {, iki dabar sunku pritaikyti, } \\
\text { kas tinka“. }\end{array}$ \\
\hline & Odos pokyčiai & 1 & $\begin{array}{l}\text {,,Vieno tipo nelabai tinka, oda trūkinèja, jeigu labai dažnai naudoju per daug, o kadangi vis tiek, } \\
\text { kiekvienam pacientui keičiam ir visa laika vis tiek naudojam tas pirštines, <...>. }\end{array}$ \\
\hline $\begin{array}{l}\text { Darbo metu } \\
\text { naudojami } \\
\text { medikamentai }\end{array}$ & $\begin{array}{l}\text { Alerginè reak- } \\
\text { cija }\end{array}$ & 1 & $\begin{array}{l}\text { „Aš asmeniškai atkreipiau dèmesị, kad man diazepamas, ampulès raminančių man netinka, aš kai } \\
\text { ja sutraukiu } i \text { švirkšta, man paraudonuoja veidas. }<\ldots>\text {, Aš tiesiog patinstu biškį “. }\end{array}$ \\
\hline
\end{tabular}




\section{Literatūra}

1. Ahwal S, Arora S. Workplace stress for nurses in emergency department. International Journal of Emergency \& Trauma Nursing 2015;1(2):17-21.

https://www.researchgate.net/publication/288981746 Workplace_Stress_for_Nurses_in_Em ergency_Department

2. Cone D, Brice JH, Delbridge TR, Myers JB. Emergency medical services: clinical practice and systems oversight, 2 volume set 2015; 2: 211.

https://doi.org/10.1002/9781118990810

3. Lu DM, Sun N, Hong S, Fan Yy, Kong Fy, Li Qj. Occupational stress and coping strategies among emergency department nurses of China. Arch Psychiatr Nurs 2015; 29(4):208-212. https://doi.org/10.1016/j.apnu.2014.11.006

4. Firdousa J, Kour S, Para MA. Coping strategies used by staff nurses working in emergency and general wards of SKIMS hospital: a comparative study. Annals of Medical and Health Sciences Research 2017;106.

https:/www.amhsr.org/articles/coping-strategies-used-bystaff-nursesworking-in-emergency-and-general-wards-ofskims-hospital-a-comparative-study.pdf

5. Gałązkowski R, Binkowska A, Samoliński K. Occupational injury rates in personnel of emergency medical services. Annals of Agricultural and Environmental Medicine 2015;22(4):680-684. https://doi.org/10.5604/12321966.1185775

6. Yuwanich N, Akhavan S, Nantsupawat W, Martin L. Experiences of occupational stress among emergency nurses at private hospitals in Bangkok, Thailand. Open Journal of Nursing 2017;7(6):657-670. https://doi.org/10.4236/ojn.2017.76049

7. Kowalczyk A, Kulczycka K, Stychno E, Chilimoniuk B. Characteristics of occupational hazards at the workplace of a nurse. Journal of Education, Health and Sport 2018; 8(9):1328-1337.

8. Kilic SP, Aytac SO, Korkmaz M, Ozer S. Occupational health problems of nurses working at emergency departments. International Journal of Caring Sciences. 2016; 9(3):10081019. http://www.internationaljournalofcaringsciences.org/ docs/30_parlar_originial_9_3\%20\%28 1\%29.pdf

9. Mossburg S, Agore A, Nkimbeng M, Commodore-Mensah Y. Occupational hazards among healthcare workers in Africa: a systematic review. Annals of Global Health 2019;85(1):78. https://doi.org/10.5334/aogh.2434

10. Ulutasdemir N, Cirpan M, Ozturk E, Tanir F. Occupational risks of health professionals in Turkey as an emerging economy. Annals of Global Health 2015;81(4):522-529.

https://doi.org/10.1016/j.aogh.2015.08.019
11. Ustundag M. The hidden part of the iceberg for emergency department staff: the burnout syndrome. Emergency Medicine 2012;2(5):e118. https://doi.org/10.4172/2165-7548.1000e118

12. Weaver MD, Patterson PD, Fabio A, Moore CG, Freiberg MS, Songer TJ. An observational study of shift length, crew familiarity, and occupational injury and illness in emergency medical services workers. Occupational and Environmental Medicine 2015;72(11),798-804.

https://doi.org/10.1136/oemed-2015-102966

\section{HEALTH RISKS TO NURSES WORKING IN EMERGENCY MEDICAL CARE \\ R. Juozapavičienè}

Keywords: risk, health problems, nurse, ambulance.

Summary: Healthcare professionals provide patient care in an environment that is considered to be one of the most unsafe in professional settings. Occupational health risks in the work environment include biological, chemical, physical, ergonomic, psychosocial, fire and explosion and electrical hazards that endanger the life, safety and well-being of healthcare workers [6].

The aim of the study. Reveal the health risks of nurses working in emergency medical care.

Research subjects: A total of 15 nurses working at X Ambulance Station participated in the study. Respondents were selected according to the purpose of the study. The targeted selection of subjects was subject to the requirement that all subjects provide emergency medical care for at least one year.

Research methodology. The study was conducted in a semistructured interview aimed at elucidating the health risks encountered during work activities. The research data is analyzed by providing a content (Content) analysis method.

Main results of empirical research. In providing emergency medical care, nurses face biological, chemical, physical, ergonomic, and psychosocial health risks. The study revealed that nurses providing emergency medical care experience stress, internal tension, and fear. They experience violence, bodily injuries, changes in the musculoskeletal system, microtrauma with sharp instruments. The risk of contracting various infectious and non-infectious diseases is caused by direct contact with a person, exposure to body fluids and exposure to medications used at work. Nurses also experience changes in physical health, such as: general fatigue, disturbance of sleep, stomach or reproductive system, change in diet, metabolism, cardiovascular system. Deterioration of mental health is affected by frequent fears, stress and the resulting internal tension.

Correspondence to: rasa.juozapavičienė@go.kauko.lt

Gauta 2020-10-26 